\title{
Zeszyty PRASOZNAWCZE
}

Kraków 2017, T. 60, nr 4 (232), s. 779-804

10.4467/22996362PZ.17.045.8187

www.ejournals.eu/Zeszyty-Prasoznawcze/

\section{ROLA AUTOPROMOCJI W ZARZĄDZANIU OFERTĄ TELEWIZYJNĄ}

\author{
MARZENA BARAŃSKA
}

Instytut Kultury

Uniwersytet Jagielloński

\section{ABSTRACT \\ The role of self-promotion in the management of the television offer}

In the second decade of the 21 st century, the activity of business entities is not only related to the production or the provision of services, but marketing activities are becoming increasingly important. Reaching potential customers with information about the offer is important in the process of pursuing economic success. Often these types of projects are accompanied by, defined in the strategies of the development of the activity, appropriately selected methods and tools of their implementation. Comprehensive design facilitates implementation, both in terms of subject and subject matter, and thus is competitive with other commodities and services exchanges.

The management of a media company requires the use of mechanisms specific to other operators to achieve a net margin. Specificity of the object of the activity, i.e. the provision of audiovisual services, inter alia it commits to programming, informs about planned broadcasts to influence the audience's choices.

Keywords: self-promotion, media management, information architecture, program 


\section{Wstęp}

Współczesne instytucje medialne stanowią integralną część rynku gospodarczego. Podobnie jak inne podmioty, ukierunkowane są na realizację wyznaczanych celów, warunkujących rozwój i konkurencyjność przedsiębiorstwa. Przedmiotem aktywności gospodarczej nadawców telewizyjnych jest świadczenie usługi medialnej, polegające m.in. na emisji programu. W przyjętej w Ustawie o radiofonii i telewizji definicji stwierdzono, że ,programem jest uporządkowany zestaw audycji, przekazów handlowych lub innych przekazów, rozpowszechniany w całości, w sposób umożliwiający jednoczesny odbiór przez odbiorców w ustalonym przez nadawcę układzie" (Dz.U. 2016, poz. 639, art. 4, pkt 6). Przygotowana oferta relatywnie do działań podejmowanych przez inne podmioty gospodarcze wymaga popularyzowania informacji i wiedzy o niej wśród potencjalnych widzów. Odpowiednio dobrane formy i narzędzia oddziaływań marketingowych mają nie tylko zachęcić, ale też przekonać widzów do obejrzenia audycji przygotowanej przez daną antenę. Praktyki promocyjne, rozwiązania właściwe dla public relations czy reklamy spowodowały, że tradycyjne formy - zapowiadanie przez spikerów programu - zostały uzupełnione przez inne działania autopromocyjne. Istotnym elementem owego „samozachwalania” jest skondensowanie informacji o programie dystrybuowanym za pośrednictwem różnych kanałów komunikacyjnych. Tak „opakowana” informacja, jak słusznie zauważa Peter Drucker ,,[...] staje się bardziej cenna, ponieważ znana jest większej liczbie osób" (Drucker 2000, s. 7). Miarą jakości przygotowanej oferty są współczynniki oglądalności. $\mathrm{Z}$ tego względu, w dobie silnej konkurencyjności na rynku medialnym, działania autopromocyjne zyskują na znaczeniu.

$\mathrm{Z}$ uwagi na wagę zagadnienia, zwłaszcza brak kompleksowego opracowania problemu, w publikacji poddano analizie kwestie dotyczące czynników warunkujących kształtowanie oferty programowej telewizji, wskazano na elementy składowe pojęcia autopromocja, jak również stosowane w praktyce rozwiązania. Mając na względzie powyższe, cel publikacji został określony jako krytyczna analiza stosowanych przez nadawców telewizyjnych form zarządzania ofertą programową. Dla potrzeb realizacji tak opisanego celu zastosowano analizę zawartości treści oraz istotne aspekty obserwacji uczestniczącej. Na kartach publikacji poszukiwano odpowiedzi na następujące pytania: „Jaką rolę w kształtowaniu relacji z widzem spełnia autopromocja?” oraz „W jakim stopniu zmiany technologiczne uwarunkowały stosowane praktyki w zakresie podejmowanych działań autopromocyjnych?".

\section{Pojęcie autopromocji}

Na wstępie podkreślić należy, że nie ma jednej, bezwzględnie obowiązującej definicji autopromocji. W potocznym rozumieniu, pojęcie to często jest używane 
jako synonim autoprezentacji, stąd w konsekwencji odnosi się do informacji, wiedzy dotyczącej umiejętności, kwalifikacji danej osoby. Podobną interpretację zamieszczono w „Słowniku języka polskiego" - to ,prezentowanie swojej wiedzy i swoich umiejętności, np. przy staraniu się o pracę" (Słownik Języka Polskiego..., hasło: autopromocja). W zakresie pojęciowym autopromocji mieszczą się takie określenia, jak: prezentowanie, obrazowanie, zachwalanie, pokaz, reklama siebie, reklama o sobie (Definicje NET...). Każde z nich zawiera element znaczeniowy wyrażający wolę wpływania na otoczenie przez wskazanie określonych właściwości i cech przypisanych danej jednostce lub stanowiących konsekwencję jej działania. Pojęcie to zostało zaadaptowane także dla potrzeb prowadzonej przez instytucje i organizacje działalności marketingowej.

Analiza terminu wymaga odniesień do obszarów ekonomicznych, marketingowych, a także ujęcia prawnego. W stosunkach gospodarczych autopromocja najczęściej ma zastosowanie w kontekście upowszechniania treści dotyczących towarów lub usług. To rodzaj samochwalenia się w celu uwypuklenia posiadanych właściwości, cech. $Z$ marketingowego punktu widzenia jest pochodną m.in. promocji, public relations, w których konstytutywnym czynnikiem oddziaływania na otoczenia jest budowanie preferencji na rynku nadawcy treści komunikatu.

Termin promocja według Richarda Harlowa oznacza: „funkcję zarządzania pomagającą ustanowić i podtrzymać wzajemne kanały komunikowania, zrozumienia, akceptacji oraz współpracy pomiędzy podmiotem a jego otoczeniem" (Harlow 1976, s. 38). Forma ta w zarządzaniu organizacją pełni rolę operatora, który pozwala na podstawie wniosków wynikających z analizy opinii publicznej, konstruowanych strategii komunikacyjnych efektywnie wykorzystujących społeczne oczekiwania, dążyć do realizacji wyznaczonych celów. Autopromocja jest pochodną promocji - jej cel jest wyraźnie zbieżny z przedmiotem działań promocyjnych, aczkolwiek skoncentrowany na podkreślaniu walorów, cech, właściwości samego podmiotu czy jego oferty. Jak wcześniej wskazano, pojęcie ,autopromocji” wymaga odwołania się do cech i właściwości charakteryzujących public relations.

Według Międzynarodowego Stowarzyszenia Public Relations (IPRA), „organizacja pozyskuje i podtrzymuje zrozumienie, sympatię i poparcie tych, którymi jest zainteresowana obecnie lub może być zainteresowana w przyszłości - przez badanie ich opinii o organizacji, w celu maksymalnego dostosowania do nich swoich celów i swojej działalności, aby osiagnąć - przez planowe, szerokie rozpowszechnianie informacji - lepszą współpracę ze społeczeństwem oraz skuteczniej realizować swoje interesy" (Cutlip, Center 1978; Budzyński 1998, s. 9). Słusznie zauważa William G. Nickels, że podstawowym zadaniem tej formy marketingu jest budowanie oceny nastawienia społecznego przez dobór odpowiednich metod i narzędzi oddziaływania (Jabłoński, Sobkowiak 2002, s. 149). Natomiast Tadeusz Sztucki zwraca uwagę na osiaganie korzystnych związów z nabywcami, otoczeniem zewnętrznym (Sztucki, 1997, s. 54). Elementy powyższe egzemplifikowane są w stanowiskach prezentowanych m.in. przez Krystynę 
Wojcik (1997, s. 22-23), Reginę Brady (Brady, Forrest, Mizerski 2002, s. 149), Edwarda Bernaysa (2011).

Mając na względzie powyższe, dla potrzeb prowadzonej analizy przyjęto, że autopromocja to integralna część zarządzania mediami, rodzaj komunikowania informacyjnego i perswazyjnego wywierającego wpływ na różne audytoria, realizowanego m.in. poprzez treści publikowane na stronach internetowych organizacji, w mediach społecznościowych, prasie drukowanej i/lub elektronicznej, telewizji, radio, a także za pośrednictwem innych praktykowanych form upowszechniania wiedzy o danej jednostce/organizacji. Autopromocją sensu stricto jest upowszechnianie informacji za pośrednictwem własnych kanałów informacyjnych; sensu largo - polega na adaptacji kanałów informacyjnych innych podmiotów i określana jest mianem cross promotion. Za inne praktykowane formy uznać należy m.in. organizowane eventy, konferencje prasowe. Adresatami ich są zarówno konsumenci, jak również kręgi opiniotwórcze.

W odniesieniu do nadawców programów telewizyjnych, podmiotów świadczących usługi audiowizualne, celem podejmowanych działań jest zachęcanie widzów do obejrzenia przygotowanej oferty, tj. programu składającego się z audycji. Przyjąć zatem można, że polega na „zachęcaniu odbiorcy do kontynuacji kontaktów z nadawcą" (Jabłoński, Sobkowiak 2002, s. 149-150).

„Samopromowanie” służy zwróceniu uwagi widowni na atrakcyjną, wyjątkową propozycję nadawcy, która będzie realizowana w niedalekiej przyszłości. Konstytutywnym elementem przekazu jest treść, którą stanowi informacja przekazana $\mathrm{w}$ formie werbalnej, audiowizualnej, audialnej wyposażająca odbiorcę w określoną wiedzę. Według Jerzego Kisielnickiego i Henryka Sroki to „rodzaj zasobów, który pozwala na zwiększenie naszej wiedzy o otaczającym nas świecie" (Kisielnicki, Sroka 2005, s. 13; por. Earl 2000). Z uwagi na zakres zawartości treści, taka wypowiedź może być kwalifikowana jako komunikat prosty, ale także pozwalający na uzyskanie przez widza szerszej wiedzy, niż tylko udzielenie odpowiedzi na pytania: „kto?”, „gdzie?”, „kiedy?”. Egzemplifikowane cechy, takie jak: właściwości, cena, zawartość towaru, kwalifikują informację/wypowiedź jako gospodarczą. Również permanentne prezentowanie znaku towarowego, logo nadawcy ma wymiar perswazyjny, np. TVN, Polsat zamieszczane najczęściej w prawym górnym rogu.

W konsekwencji można skonstatować, że autopromocja jest to rodzaj komunikatu zawierającego treść o charakterze komercyjnym, pochodzącego od nadawcy mającego na celu zarekomendowanie oferty programowej dostawcy ${ }^{1} \mathrm{i} / \mathrm{lub}$ jego usługi, aby wpłynąc na procesy decyzyjne potencjalnych widzów. Przyjęta kon-

1 Zgodnie z art. 1 pkt d. Dyrektywy Parlamentu Europejskiego i Rady 2010/13/UE z dnia 10 marca 2010 r. w sprawie koordynacji niektórych przepisów ustawowych, wykonawczych i administracyjnych państw członkowskich dotyczących świadczenia audiowizualnych usług medialnych - „dostawca usług medialnych” oznacza osobę fizyczną lub prawną, która ponosi odpowiedzialność redakcyjną za wybór audiowizualnej treści audiowizualnej usługi medialnej i decyduje o sposobie zestawienia tej treści, Dz.Urz. UE z dnia 15 kwietnia 2010, L 95/1. 
cepcja pozwala na wyróżnienie działań prowadzonych we własnym zakresie, jak również wspólnie, w porozumieniu z innymi nadawcami czy wydawcami.

Formalne ujęcie autopromocji zawarto w Dyrektywie Parlamentu Europejskiego i Rady 2010/13/UE z dnia 10 marca 2010 r. w sprawie koordynacji niektórych przepisów ustawowych, wykonawczych i administracyjnych państw członkowskich dotyczących świadczenia audiowizualnych usług medialnych (dyrektywa o audiowizualnych usługach medialnych). Stwierdzono, że są to „ogłoszenia nadawcy w związku z jego własnymi audycjami lub w związku z produktami towarzyszącymi, wywodzącymi się bezpośrednio z tych audycji” (Dz.Urz. UE 15.04.2010.L 95/1). Z normatywnego punktu widzenia ,[...] działania autopromocyjne stanowią szczególną formę reklamy, w której nadawca telewizyjny promuje własne produkty, usługi, programy lub kanały; w szczególności zwiastuny zawierające urywki programów powinny być traktowane jak programy" (Dz.Urz. UE 15.04.2010.L 95/1). Zdaniem autorki, użyty zwrot „szczególna forma reklamy" nie przesądza o kwalifikowaniu wszystkich działań autopromocyjnych jako reklamy. Jeżeli dostawca, emitując komunikat, ma na celu jedynie informowanie o ofercie, to treść przekazu spełnia znamiona pojęcia informacji handlowej ${ }^{2} \mathrm{i}$ wówczas ma wymiar promocyjny. Inicjowane przez nadawcę programu przedsięwzięcia, mające przekonać widza do wyboru audycji tej konkretnej stacji, anteny (własnych usług, programów, kanałów) albo innych audycji zazwyczaj tego samego dostawcy usługi, zawierające elementy wartościujące, zachwalające stanowią asumpt dla kwalifikowania jako reklam. Podejście takie potwierdza motyw 96 oraz art. 1 pkt i Dyrektywy Parlamentu Europejskiego i Rady z dnia 10 marca 2010 roku $^{3}$. Podkreślić należy, że obowiązujące w Polsce rozwiązanie prawne, zawarte w art. 4 pkt. 17 Ustawy z dnia 29 grudnia $1992 \mathrm{r}$. o radiofonii i telewizji, jednoznacznie kwalifikuje autopromocję jako reklamę, co z punktu widzenia dostawców usług jest niekorzystne z uwagi na obowiązujące limity emisji spotów reklamowych.

Treść przekazu stanowi istotne kryterium w zakresie kwalifikowania tego typu wypowiedzi. Przypomnieć należy, że z punktu widzenia marketingowego osobliwością reklamy (por. Namysłowska 2012) jest eksponowanie cech i właściwości przypisanych towarom/usługom reklamodawcy w celu agitowania do ich naby-

2 Art. 2, pkt f, Dyrektywy Parlamentu Europejskiego i Rady 2000/31/WE z dnia 8 czerwca 2000 r. w sprawie niektórych aspektów prawnych usług społeczeństwa informacyjnego, w szczególności handlu elektronicznego w ramach rynku wewnętrznego (dyrektywa o handlu elektronicznym), stanowi, że informacją handlową jest: każda forma informacji przeznaczona do promowania, bezpośrednio lub pośrednio, towarów, usług lub wizerunku przedsiębiorstwa, organizacji lub osoby prowadzącej działalność handlową, gospodarczą, rzemieślniczą lub wykonującą zawód regulowany (Dz.Urz. L 178, 17.07.2000 P. 0001-0016).

3 Zgodnie z art. 1 pkt i ,reklama telewizyjna” oznacza wszelkiego rodzaju ogłoszenia związane z działalnością handlową, gospodarczą, rzemieślniczą lub działalnością w ramach wolnego zawodu rozpowszechniane przez przedsiębiorstwo publiczne lub prywatne lub osobę fizyczną w zamian za opłatę lub podobne wynagrodzenie lub rozpowszechniane przez to przedsiębiorstwo lub tę osobę fizyczną w celach autopromocji w celu promocji odpłatnego dostarczania towarów lub świadczenia usług, w tym nieruchomości, praw i zobowiązań. 
wania. Informacje proste, udzielające odpowiedzi na zasadnicze pytania: „co?”, „gdzie?”, „kiedy?”, zakwalifikować należy jako właściwe promocji. Wzbogacone zaś o elementy zachęcające, wartościujące daną audycję, często uzupełnione prezentowanymi fragmentami emitowanych treści, czy specjalnie przygotowane audycje stanowiące integralną część programu to osobliwości reklamy. W tym kontekście autopromocję umiejscawiać należy ,gdzieś pomiędzy audycją (zasadnicza kategoria przekazów nadawanych w programie) a reklamą (kategoria przekazów mimo wszystko mających charakter promocyjny), co summa summarum nie jest jednoznaczne z pozbawieniem autopromocji cech reklamy" (Traple 2007, s. 261). „Zapowiedź następnych audycji należy zaś uznać za ich promocję, jako że ma ona na celu zachęcić widza do dalszego oglądania programu danego kanału, anteny"4.

Analiza zaprezentowanych definicji pozwala na stwierdzenie, że konstytutywnymi cechami przekazu autopromocyjnego są: audiowizualność treści pochodząca od nadawcy, dotycząca świadczonych przez niego usług, oraz działanie podejmowane $\mathrm{w}$ celu promocji oferty. W odniesieniu do nadawcy telewizyjnego

ta forma autopromocji przybiera postać ramówkową (wsparcie całej ramówki: jesiennej albo wiosennej, kiedy to wprowadzane są nowości i kolejne edycje sprawdzonych hitów); pasmową (działanie na rzecz kilkugodzinnych bloków programów, spójnych w kontekście danego tematu, np. filmowego, porannego) i programową (odnosi się wyłącznie do pojedynczych produktów medialnych: konkretnego show, filmu albo serialu). Zazwyczaj ich cykl życiowy rozpoczyna się i kończy na antenie telewizyjnej (Jupowicz-Ginalska 2013, s. 239).

O ile reklama zazwyczaj wskazuje na właściwości jednego, prezentowanego towaru lub usługi, to autopromocja anonsuje ,zbliżające się audycje”.

Nie ulega wątpliwości, że autopromocja w zarządzaniu mediami stanowi narzędzie w zakresie osiaggania sukcesu komercyjnego stacji telewizyjnej.

\section{Determinanty ramówki telewizyjnej - wybrane zagadnienia}

Nadawca telewizyjny, podobnie jak inne struktury organizacyjne, jest przedsiębiorstwem, a zatem jednym z jego celów jest osiagnięcie zysku. Za Bogusławem Nierenbergiem należy przyjąć, że ,zarządzanie mediami (w ujęciu systemowym) to zespół wzajemnie powiązanych procesów i czynności obejmujących: planowanie, organizowanie, przewodzenie i motywowanie oraz kontrolowanie, odnoszących się do wszystkich przejawów i poziomów systemu medialnego" (Nierenberg, 2011, s. 79). Optymalny układ jednostek tworzących organizację, m.in.: kadra, proces technologiczny, sprzyjać mają jej rozwojowi.

4 W przedmiocie wykładni przepisów normujących reklamę telewizyjną i sponsorowanie przez przedsiębiorstwa audycji telewizyjnych - opinia z 6 października 2015 r. [http://www.korporacyjnie. $\mathrm{pl} /$ w-przedmiocie-wykladni-przepisow-normujacych-reklame-telewizyjna-i-sponsorowanie-przez-przedsiebiorstwa-audycji-telewizyjnych-opinia-z-6-pazdziernika-2015-r/]. 
Specyfika działalności przedsiębiorstw medialnych wynika z przedmiotu prowadzonej aktywności gospodarczej - emisji przekazu audiowizualnego. Celem jest tworzenie, emisja, dystrybucja ustalonych w określonym porządku treści audialnych i wizualnych (programu), w zakresie kultury, informacji i rozrywki. Zarządzanie telewizją obejmuje m.in. utworzenie układu audycji, zatem programu, który jest postrzegany jako produkt na sprzedaż, na którym zarabia nadawca. Słusznie zauważa Agnieszka Garcarek-Sikorska, że ,walka o audytorium powoduje u nadawców wprowadzanie strategii programowych nakierowanych na atrakcyjne «opakowanie» i sprzedanie swoich własnych produktów - audycji" (Garcarek-Sikorska 2013, s. 202). Zobowiązuje to zarządy organizacji medialnych do podejmowania decyzji dotyczących architektury informacji. Pojęcie ,,architektura informacji” przyjęto za Louisem Rosenfeldem i Peterem Morville'em - „to sposób organizacji informacji w przestrzeni (np. medialnej), nadawania im nazw rozpoznawczych (tzw. etykietowanie elementów informacyjnych) oraz tworzenie schematów przeszukiwania $\mathrm{w}$ systemie informacyjnym na potrzeby podmiotów medialnych" (Rosenfeld, Morville 2003, s. 5). W strukturze projektowania aktywności medialnej nadawcy dokonują taksowania treści, uwzględniając następujące elementy składowe:

- całościowe systemy organizacyjne odpowiadają za podział informacji na kategorie według grupowania treści i cech;

- systemy etykietowania określające, w jaki sposób informacja jest opisywana w wydzielonych kategoriach, klasach, tzw. porządkowanie zbiorów;

- systemy wyszukiwania odpowiadające za metody i prezentacje informacji w zależności od potrzeb zadaniowych realizowanych w podprzestrzeni zarządzania (Gawroński 2014, s. 423).

Kompleksowe opracowanie rozwiązań w zakresie zawartości treści przekazu, podział na pasma emisji i sposób poinformowania opinii publicznej o przygotowanej ofercie, stanowić będą o wyborach dokonywanych przez widownię.

Zadaniowość, wynikająca z potrzeby rekonstrukcji już oferowanego programu telewizyjnego czy opracowania nowego, stanowi konsekwencję wnikliwej oceny otoczenia zewnętrznego, możliwości ekonomicznych i kadrowych autora „ramówki”. Termin ramówka w żargonie dziennikarskim oznacza ofertę programową. Jej tworzenie jest następstwem permanentnie prowadzonych analiz danych statystycznych dotyczących poziomu oglądalności dotychczas emitowanego programu, upodobań widzów w zakresie używanych do odbioru urządzeń, co stanowi podstawy dla zarządzania audycjami. O poziomie oglądalności decydują stosowane w zakresie przesyłania przekazu technologie.

Digitalizacja sprzyja jednoczesnej emisji przekazu za pośrednictwem różnych urządzeń, w różnych miejscach i o dogodnej dla odbiorcy porze. Mimo wielu zapowiedzi sprzed lat telewizja - jako medium kwalifikowana jako tradycyjny nadawca - nadal jest jednym z najpowszechniejszych nośników informacji. $Z$ danych statystycznych wynika, że telewizja jest cały czas w Polsce najważniejszym medium. 
Odbiornik telewizyjny posiada $96,7 \%$ gospodarstw domowych. W $77 \%$ gospodarstw jest to telewizor LCD lub plazmowy. [...] Dla porównania, komputer przenośny można spotkać w 59\% gospodarstw, a stacjonarny w $40 \%$, mimo że w zasięgu Internetu znajduje się $71 \%$ gospodarstw domowych. Zmiana, jaka nastąpiła w ofercie programowej dzięki wprowadzeniu naziemnej telewizji cyfrowej, spotkała się z pozytywnym odzewem ze strony odbiorców. Większość z nich jest zdania, tak jak rok wcześniej, że oferta bezpłatnej telewizji jest lepsza, niż była kiedyś. Opinię tę podzielają również abonenci sieci kablowych i satelitarnych. Uzasadniając pozytywną ocenę, widzowie naziemnej telewizji cyfrowej wskazują przede wszystkim większą liczbę dostępnych programów (70\%), wysoką jakość obrazu i dźwięku (55\%) oraz ciekawsze audycje (53\%). Blisko 40\% widzów przyznaje, że po pojawieniu się naziemnej telewizji cyfrowej ogląda telewizję dłużej niż kiedyś" (Informacja o podstawowych problemach radiofonii i telewizji... 2015, s. 12) . $^{5}$

Dla współczesnego widza istotna jest szybkość dostarczenia przekazu od nadawcy do odbiorcy, jakość usługi, zawartość treści przekazu - wszystko to wpływa na zachowanie potencjalnych widzów, ale także działania konkurencji. Rywalizacji poszczególnych nadawców sprzyjają rozwiązania technologiczne: przekaz nadawany równolegle drogą naziemną cyfrową oraz w sieci - multiscreening. Bogata oferta treści audiowizualnych i coraz szerszy wybór urządzeń do ich odbioru gwarantują zwiększający się udział nadawcy w ,zagospodarowywaniu” widowni. Multiscreening, czyli zjawisko korzystania z wielu ekranów jednocześnie, dotyczy już blisko 70\% użytkowników Internetu (Multiscreening...).

Podczas oglądania telewizji internauci najchętniej korzystają z telefonu komórkowego (48\%), który służy im przede wszystkim do odwiedzania portali społecznościowych, lub z laptopa (43\%), na którym sprawdzają wiadomości i szukają różnego typu treści. [...]. Multiscreening występuje najczęściej wśród osób do 24. roku życia. Z portali społecznościowych podczas oglądania telewizji korzysta $55 \%$ osób z tej grupy wiekowej. Innym zjawiskiem charakterystycznym dla internautów jest tzw. shifting, czyli wykorzystywanie kilku urządzeń po kolei do tego samego celu. Takie zachowania deklaruje 55\% badanych internautów, którzy najczęściej korzystają z telefonu i komputera (Informacja o podstawowych problemach radiofonii i telewizji... 2015, s. 14-15).

Rozwiązania technologiczne stworzyły nowe możliwości w zakresie dystrybuowania informacji dotyczących oferty programowej.

Kolejnym novum w eterze stała się inna niż dotychczas rola odbiorcy. W modelowym, kanonicznym wzorcu, audycje pozbawione były cech interaktywności (jedyną formą kontaktu były listy do redakcji, później ewentualnie telefony oraz sondy uliczne). Pojawienie się komercyjnych rozgłośni zainicjowało udział słuchacza, a później również internauty, w kreowaniu kształtu i tematyki programów (Garcarek-Sikorska 2013, s. 203).

5 Istotnym czynnikiem jest tzw. pokrycie kraju, będące wynikiem usytuowanych na terenie kraju nadajników, za pośrednictwem których emitowany jest przekaz. Możliwość dotarcia do jak największej grupy widowni nie pozostaje bez wpływu na atrakcyjność medium jako nośnika informacji. 
Zarządzanie organizacją wymaga także analizy otoczenia zewnętrznego, a zwłaszcza działań podejmowanych przez konkurencję. Pluralizm oznaczający wielość na rynku medialnym aktorów o zróżnicowanym statusie organizacyjnym - równolegle funkcjonują nadawcy publiczni, prywatni i społeczni - generuje potrzebę opracowywania kompleksowych planów rozwoju, zwłaszcza w kontekście wskazania grup targetowych i określenia ich preferencji.

Dzisiejszy popyt na rynku przekazów tworzą dwa rodzaje potrzeb: informacyjne
i rozrywkowe. Elementem różnicującym na rynku medialnym nie jest cena, jak
w przypadku rynków klasycznych, gdzie to właśnie koszt ponoszony przez klienta
decyduje o relacjach popytu i podaży. Taką kategorią w mediach jest czas, jaki od-
biorca poświęca danemu przekazowi, i to on stanowi walutę decydującą o wyborze
konkretnego rozwiązania (Szmelter 2015, s. 133).

W konsekwencji wpływa nie tylko na układ programu, ale także tworzenie tzw. kanałów telewizyjnych oferujących widzowi wyspecjalizowana tematykę, $\mathrm{np}$. adresowanych do dzieci, osób zainteresowanych historia, sportem.

W opublikowanym w grudniu 2015 raporcie „International Communications Market" stwierdzono, że wzrasta liczba osób oglądających telewizję, a przeciętny czas, jaki osoba spędza przed odbiornikiem, wynosi około pięciu godzin na dobę (zob. Rączka 2015). Istotna jest także wiedza o preferowanych formach, gatunkach dziennikarskich, zainteresowaniach widzów danym tematem, problematyka, jak również struktura czasu dobowego, jaki wpływa na poziom zainteresowania daną anteną, a zatem i ofertą. Wskazane czynniki determinują układ „ramówki”.

Miarą jakości programu stają się m.in. cyfry odzwierciedlające poziom oglądalności audycji, jakości programu, determinujące wartość czasu antenowego. Za celową uznać należy instrumentalizację kanałów komunikacji, niezbędnych dla transferowania treści wpływających na kształtowanie, utrzymanie i wybory dokonywane przez potencjalnych widzów danej stacji czy anteny.

Media stają się więc zarówno nadawcami, pośrednikami, jak i odbiorcami przeka-
zów marketingowych, a jednocześnie ich nośnikami, zwielokratniającymi i roz-
powszechniającymi je na pożądaną przez nadawców/wydawców skalę (Jupowicz-
-Ginalska 2010, s. 23).

To uwarunkowana technologicznie, fundamentalna zmiana paradygmatów w sferze komunikowania społecznego, z udziałem mediów.

\section{Praktyki autopromocyjne nadawców}

Rozwój nowych technologii, marketingu stworzył nową przestrzeń dla prowadzenia promocji mediów w mediach. Według Anny Jupowicz-Ginalskiej wyróżnić można cztery typy promocji: 1) autopromocja; 2) cross-promocja właścicielska; 3) promocja zewnętrzna; 4) promocja mieszana (Jupowicz-Ginalska, 2010, s. 189-190). Wymienione typy mogą być w praktyce realizowane zarówno kompleksowo, jak i wybiórczo, z uwagi m.in. na charakter struktury organizacyjnej 
danego nadawcy, preferowane w danym okresie narzędzia oddziaływań i kanały informacyjne. Media promują siebie za pośrednictwem własnych kanałów komunikacyjnych, jak i we współpracy z innymi wydawcami, nadawcami.

Do najczęściej praktykowanych form z zakresu autopromocji zaliczyć należy:

1. zapowiedzi spikerów/prezenterów programów telewizyjnych,

2. zamieszczanie ogłoszeń,

3. specjalnie przygotowane audycje,

4. konkursy,

5. techniczne formy eksponowania informacji na ekranie odbiornika.

1. Budowanie wizerunku stacji telewizyjnej uwarunkowane jest nie tylko przygotowaną ofertą programową, współczynnikami oglądalności, wyrażanymi opiniami, lecz istotne znaczenie ma kadra. Każda stacja telewizyjna, antena dysponuje zespołem spikerów, których wiodącym zadaniem jest przedstawianie oferty programowej zgromadzonej przez odbiornikiem widowni. Dotychczasowe praktyki informowania opinii publicznej o zbliżającej się emisji audycji przez prezenterów danej anteny nie zostały zaniechane, a takie postaci, jak Jan Suzin $^{6}$, Edyta Wojtczak ${ }^{7}$, Bogumiła Wander ${ }^{8}$ czy Krystyna Loska ${ }^{9}$ wyznaczyły kanony zachowań dla przyszłych pokoleń spikerów (Sobczyński 2012). W tzw. „wejściach do studia telewizyjnego" spiker, najczęściej w pozycji siedzącej, zza biurka, zapraszał widzów do obejrzenia kolejnych audycji. Współcześnie forma uległa zmianie. Na tle specjalnie przygotowanej scenografii w studio osoba/osoby (duet) informują o najbliższej audycji, jak i kolejnych propozycjach programu.

O popularności stacji telewizyjnej decyduje nie tylko przygotowany program, konkurencyjny względem innych nadawców, ale także osobowości. Miła aparycja, sposób przekazywania treści, długoletnia obecność w telewizji wpływają na proces kojarzenia osoby - prezentera/spikera $z$ daną anteną. Sympatia opinii publicznej, zaufanie do nich, wiarygodność wypowiedzi przyczyniają się do kształtowania pozytywnego wizerunku stacji. Nie jest wykluczone, by osoby będące prezenterami prowadziły programy autorskie czy inne audycje, np. Paulina Chylewska, Anna Popek, Magda Mołek.

6 Jan Suzin pracę w TVP rozpoczął w połowie lat 50. XX wieku (1955 r.), a zakończył 26 listopada 1996 r. Był jednym z dwóch pierwszych (obok Eugeniusza Pacha) lektorów TVP. Wystapił w pierwszym wyemitowanym programie. Z wykształcenia architekt - ukończył Politechnikę Warszawska, należał do zespołu projektującego warszawską MDM - przez niemal całe życie zawodowe był związany z TVP [http://www.tvn24.pl].

7 Była spikerką TVP od roku 1957 do 1996, później współtworzyła poranne pasmo w rozpoczynającej swoją działalność telewizji TVN (własny program „Między kuchnią a salonem”). Przez wiele lat zapowiadała programy w obu antenach TVP, a po ich osobowym zróżnicowaniu w latach 80. pracowała w TVP 1 [https://pl.wikipedia.org/wiki/Edyta_Wojtczak].

8 Rozpoczęła pracę w TVP w latach 60. minionego stulecia, zakończyła w roku 2003. Na podstawie: Wszystko w życiu mi wyszło [http://www.se.pl/rozrywka/gwiazdy/wszystko-w-zyciu-mi-wyszo_82568.html].

9 Pracę w telewizji rozpoczęła w latach 50. Zasłynęła tym, że przedstawiała z pamięci program na cały dzień [http://www.se.pl/rozrywka/gwiazdy/krystyna-loska-konczy-76-lat-wyglada-na-tyle_342104.html]. 
Pozytywny odbiór przez opinię publiczną stanowi także następstwo umiejętnego zarządzania personal branding. Jednocześnie pamiętać należy, iż tzw. „twarze telewizji" często są ograniczone w swobodzie wyboru dodatkowo wykonywanych prac - poprzez zapisy zawarte w kontraktach, tj. zakazy konkurencyjnych działań. Nie pozbawia to jednak prezenterów możliwości angażowania się w roli konferansjerów podczas różnych uroczystości, eventów, koncertów, gali itp., jednak za uprzednią zgodą pracodawcy - zarządu telewizji. Kojarzenie osoby z daną stacją, anteną wzmacnia wizerunek nadawcy, u którego jednostka jest zatrudniona i z którym jest utożsamiana. Osobowość spikera, jego profesjonalizm oddziałuje na organizację, podobnie jak negatywne przejawy jego aktywności ${ }^{10}$.

2. Termin ogłoszenie pojmować można jako informację, którą nadawca chce przekazać odbiorcy osobiście lub za pośrednictwem nośników informacyjnych (Dz.U. 1984, nr 5, poz. 24 z późn. zm., art. 36). Najczęściej praktykowane formy to: zapowiedzi programowe lub ogłoszenie nadawcy.

Zapowiedzi programowe prezentowane na ekranie TV zawierają charakterystykę audycji; lektor ${ }^{11}$ podaje $^{12}$ informacje dotyczące czasu emisji audycji oraz krótki jej opis, zawierający elementy zachęty, np.:

„Pomystowa zabawa” - W każdy weekendowy poranek ok. 9:00 oraz popolu-
dniami ok. 16:00. W weekendowym cyklu „Pomystowa zabawa” zapraszamy na
spotkania z bohaterami, którzy nigdy się nie nudza i maja wiele pomystów na kre-
atywne spedzenie wolnego czasu. W tym czasie na antenie zagoszcza m.in. ,Ćwier-
kajace historie”, , Kit i Kate” oraz ",Strażnicy miasta - zabawkowy kqcik Rufusa
Kłopotka" "13.

Dodatkowo, w celu wzbudzenia zainteresowania podkreśla się, że jest to premiera, nowość, odcinek premierowy, a także używane są frazy typu: sprawdź, co jest $w$ najbliższym czasie na naszej antenie, Nie przegap tego. Werbalne jak i graficzne prezentacje podkreślają atrakcyjność audycji.

Podawane przez spikerów komunikaty z uwagi na zakres przekazywanych treści można podzielić na:

- wypowiedzi informujące odbiorców o kolejnej audycji poprzez podanie treści dotyczącej tytułu i godziny emisji, niekiedy zawierającej elementy dodatkowe o walorach zachęcających;

- wypowiedzi uzupełnione o informacje dotyczące m.in. nagród, wyróżnień, jakimi dana produkcja audiowizualna została uhonorowana, np. $z$ dobywca

10 Statuty i regulaminy nadawców zawierają ograniczenia w zakresie podejmowania pracy poza aktywnością zawodową. Brak ich przestrzegania powodować może zastosowanie przewidzianych sankcji, np. upomnienia, nagany, a nawet rozwiązanie umowy o pracę.

11 Prezenter (dawniej spiker od ang. speaker) - dziennikarz zapowiadający poszczególne programy w stacji radiowej lub telewizyjnej, także prowadzący program estradowy, informacyjny, blok tematyczny lub inny program składający się z części.

12 Wykorzystywana jest zarówno technika off, jak również prezenterzy występują w studio telewizyjnym. Technika „off” - „Głos ludzi dochodzący spoza ekranu przy nieobecności mówiącego człowieka na ekranie" (Lewicki 1997, s. 234-237).

13 Zapowiedzi programowe Polsat JimJam - sierpień 2016. 
wielu Oscarów, nagrodzony Złotymi Lwami, lub nazwiska występujących aktorów.

Pierwszy typ komunikatów, zawierających wiedzę ,podstawową” o anonsowanej audycji/audycjach oraz zaproszenie widowni do jej obejrzenia, spełnia, w ocenie autorki, kryteria informacji handlowej. Drugi zaś daje przesłanki do kwalifikowania go jako przekazu reklamowego (Dz.U. 2011, nr 150, poz. 895 z późn. zm.). Z uwagi na brak wyraźnie sformułowanych kryteriów co do kwalifikowania wypowiadanych treści, w praktyce powstaje wiele kontrowersji, co uzasadnia oczekiwania dostawców programów w zakresie redefinicji pojęcia autopromocji.

Rekomendacja własnej oferty może być prowadzona samodzielnie, jak również łącznie z reklamą; wówczas najczęściej używane jest oznaczenie „reklama” lub „ogłoszenie płatne” (Dz.U. 2011, nr 150, poz. 895, § 3 ust. 3). Zawartość komunikatu stanowią tzw. trailery, czyli ,fragmenty filmu emitowane wielokrotnie jako jego zapowiedzi programowe" (Słownik Diki, hasło: trailer). Na ich tle słyszymy głos lektora ${ }^{14}$ zapowiadającego następną audycję lub kolejne propozycje programu. W praktyce powyższe informacje przekazywane są także równolegle z emisją napisów końcowych wyemitowanego materiału. „Poziom emisji głosu nie może przekroczyć poziomu głośności audycji poprzedzającej i następnej” (zob.: Dz.U. 2011, nr 150, poz. 895). Zaznaczyć należy, że wyemitowanie informacji zbyt wcześnie może naruszać przepisy prawne.

Sytuacja taka miała miejsce podczas emisji w Polsacie „Życia Pi”: ,[...] duża cześć kluczowego monologu głównego bohatera pod koniec filmu została zagłuszona przez komunikat lektora promujący nadchodzące programy stacji. Powinien on zostać nadany dopiero podczas napisów końcowych, ale pojawił się wcześniej” (KRRiT dostała skargę, więc zajmie się autopromocją...). Skarga wniesiona do Krajowej Rady Radiofonii i Telewizji - jako organu kontrolnego - została rozstrzygnięta na korzyść nadawcy. W uzasadnieniu decyzji podano, że „[...] przyczyną wadliwej emisji były kłopoty techniczne nadawcy” (Bez kary dla Polsatu za autopromocję...).

W audycji autopromocyjnej materiał jest oddzielony od pozostałej części programu dżinglem i planszą z napisem - najczęściej „ogłoszenie nadawcy” (Dz.U. 2016, poz. 639, art. 16) lub „autopromocja” (Dz.U. 2011, nr 150, poz. 895, § 6 ust. 1$)^{15}$, który powinien być ,[...] widoczny przez cały czas jej trwania [...]" (Dz.U. 2011, nr 150, poz. 895, § 4 ust. 1). „W tym aspekcie obowiązki w zakresie zamieszczania bloków reklamowych są podobne, różnią się indyferentnością

14 Poziom emisji głosu nie może przekroczyć poziomu głośności audycji poprzedzającej i następnej.

15 Ogłoszenia nadawców telewizyjnych, o których mowa w art. 16 ust. 4 pkt 1 i 2 ustawy, powinny być oznaczone wizualnie lub dźwiękowo w sposób niebudzący wątpliwości, że pochodzą od nadawcy, oraz wyodrębnione od innych części programu i przekazów handlowych. Rozporządzenie Krajowej Rady Radiofonii i Telewizji z dnia 30 czerwca 2011 r. w sprawie sposobu prowadzenia w programach radiowych i telewizyjnych działalności reklamowej i telesprzedaży, Dz.U. 2011, nr 150, poz. 895 . 
używanych oznaczeń dla tego typu audycji. Czas przeznaczony na działania autopromocyjne nie jest wliczany do czasu emisji reklam" (Dz.U. 2011, nr 150, poz. $895, \S 6$ ust. 4).

Przypomnieć należy, iż w przyjętej w roku 2010 Dyrektywie Parlamentu i Rady 2010/13/UE (Dz.Urz. UE 15.04.2010.L 95/1) ujednolicono dotychczas obowiązujące rozwiązania w zakresie definiowania zachowań nadawców telewizyjnych popularyzujących własną ofertę programową.

Dzienny czas emisji, przydzielony dla obwieszczeń zamieszczanych przez nadawcę telewizyjnego w związku z własnymi programami i dodatkowymi produktami bezpośrednio z nich uzyskiwanymi lub obwieszczeń w interesie społecznym czy też apeli charytatywnych nadawanych nieodpłatnie, nie powinien być wliczany do maksymalnej długości dziennego lub godzinowego czasu emisji, który może być przydzielony na reklamę i telezakupy.

W celu uniknięcia zakłóceń konkurencji odstępstwo to powinno być ograniczone do obwieszczeń dotyczących produktów spełniających podwójny warunek, czyli produktów dodatkowych i jednocześnie bezpośrednio uzyskiwanych z programów, których to dotyczy. Pojęcie „dodatkowy” odnosi się do produktów przeznaczonych szczególnie do umożliwienia oglądającym widzom korzystania w pełni z tych programów lub brania w nich udziału (Dz.Urz. UE 15.04.2010.L 95/1, preambuła, pkt 97-98). Artykuł 23 ww. aktu prawnego, określa limity czasowe przeznaczone na emisję reklamy. „Czas nadawania telewizyjnych spotów reklamowych i spotów telesprzedażowych nie może w danej godzinie zegarowej przekraczać $20 \%$ ”. Wskazany przedział czasu nie odnosi się do „,[...] ogłoszeń nadawcy w związku z jego własnymi audycjami ani w związku z produktami towarzyszącymi wywodzącymi się bezpośrednio z tych audycji, do ogłoszeń sponsorowanych ani do lokowania produktu" (Dz.Urz. UE 15.04.2010.L 95/1, art. 23 ust. 2). Do wskazanych limitów jednakże nie wlicza się ogłoszeń nadawcy, jeśli czas ich nadawania nie przekracza 2 minut w ciagu godziny zegarowej (Dz.U. 2016, poz. 639, art. 16 ust. 4 pkt 1 i 2).

Artykuł 23 ust. 2 dyrektywy (Dz.Urz. UE 15.04.2010.L 95/1) wyłącza więc wprawdzie tego rodzaju przekazy z limitu czasu przeznaczonego na reklamę, podlegają one natomiast co do zasady pozostałym przepisom dyrektywy dotyczącym reklamy telewizyjnej, w tym zawartemu w jej art. 19 ust. 1 obowiązkowi wyraźnego oddzielenia od treści redakcyjnych. Dodatkowo motyw 96 dyrektywy 2010/13 wskazuje, że zwiastuny zawierające urywki audycji powinny być traktowane jak audycje. A contrario zatem zapowiedzi audycji niezawierające takich urywków, na przykład wskazujące jedynie ich tytuły, również powinny być wyraźnie oddzielone od treści redakcyjnych, a także od innych form reklamy. Następstwem zaliczenia czasu przeznaczonego na emisję autopromocji do reklamy jest zmniejszenie limitu emisji spotów reklamowych w ciagu godziny czy dnia ${ }^{16}$.

16 Artykuł 23 Dyrektywy 2010/13/UE stanowi: ust. 1. Czas nadawania telewizyjnych spotów reklamowych i spotów telesprzedażowych nie może w danej godzinie zegarowej przekraczać $20 \%$. 
Ograniczenie to nie obejmuje emisji przekazów na dowolnym urządzeniu, np. laptopy.

3. Od kilku lat nadawcy telewizyjni włączyli do oferty programowej, specjalne audycje poświęcone tylko eksponowaniu oferty programowej. „Programator” w TVN, „Kinematograf” czy zapowiedzi programowe w Polsacie oraz innych stacjach to samodzielne audycje wyodrębnione od pozostałej części, zawierające treści dotyczące przyszłych emitowanych audycji. Zatem użyta nazwa własna wyróżnia tę audycję od innych zapowiedzi programowych konkurencyjnych anten, stanowiąc jej tytuł. Przypomnieć należy, iż zgodnie z obowiązującymi rozwiązaniami prawnymi termin audycja oznacza „część programu radiowego lub telewizyjnego, stanowiącą odrębną całość ze względu na treść, formę, przeznaczenie lub autorstwo" (Dz.U. 2016, poz. 639, art. 4 ust. 5).

W obszarze wizualnym, zarówno użyte barwy, jak stosowane rozwiązania techniczne: statyczny czy dynamiczny obraz, częstotliwość wprowadzanych zmian graficznych, stanowią prerogatywę nadawcy. W celu wzmocnienia, wyróżnienia graficy komputerowi często zmieniają oprawę, dostosowując ją do okoliczności, np. uroczystości, świąt, pór roku. Symboliczne ukazywane postaci Mikołaja, reniferów, kurcząt, zajęcy nie tylko przypominają o świętach, ale nadają komunikatowi wymiar emocjonalny ${ }^{17}$. Niekiedy przekazom towarzyszy dodatkowo hasło, np. Włacz emocje - Polsat Święta Bożego Narodzenia 2015.

Integralnym elementem przekazu jest logo nadawcy, co pozostaje w subsumcji z filozofią budowania corporate identity, visual identity (CI). Wskazanie w treści tzw. „tyłówki” informacji dotyczących wkładu i zakresu prac osób, które przyczyniły się do powstania audycji, potwierdza jej samodzielność. Czasami może zawierać element dodatkowy, np. odwołanie do długofalowej obecności na rynku, popularności stacji wśród widzów, np. w formie hasła od dziesięciu lat programowo najlepsza ${ }^{18}$.

Nie bez znaczenia dla poziomu percepcji widza i budowania wizerunku pozostaje oprawa muzyczna. Charakterystyczne linie melodyczne dżingli mają u widza dodatkowo wywołać proces kojarzenia $\mathrm{z}$ daną stacją. W warstwie wizualnej treść przekazu autopromocyjnego mogą także stanowić fragmenty zapowiadanych projekcji filmowych, np. wybrane sceny z fabuły audycji, zwracające uwagę potencjalnego widza swoją wartkością, linią melodyczną, wizerunkiem znanego

2. Ustępu 1 nie stosuje się do ogłoszeń nadawcy w związku z jego własnymi audycjami ani w związku z produktami towarzyszącymi wywodzącymi się bezpośrednio z tych audycji, do ogłoszeń sponsorowanych ani do lokowania produktu. Także art. 16 ust. 4 Ustawy z dnia 29 grudnia 1992 r. o radiofonii i telewizji. Tekst jednolity. Dz.U. 2016, poz. 639.

17 Często stosowane są przebitki czyli „Ujęcie spełniające wielorakie funkcje: (1) informacyjną, (2) rolę akcentu, (3) pokazuje akcję dziejącą się w innym miejscu, (4) pokrywa wszelkie «dziury» (brak ciagłości itp.) głównego ujęcia. Zazwyczaj krótkie. Praktykowane w filmie, w telewizji i bardzo często w wywiadach dokumentalnych" (Lewicki 1997).

18 Taki slogan został zamieszczony na planszy końcowej stacji TVN 22.09.2007 r. [https://www. google.pl/search?q=programator + tvn + obraz\&espv $=2 \& b i w=1360 \& b i h=634 \&$ tbm $=$ isch \&tbo $=u \&$ so urce $=$ univ\&sa $=X \& v e d=0$ ahUKEwjO_KC2zL_SAhXMWCwKHcsMD04QsAQIGQ]. 
aktora. Podczas ich rozpowszechniania lektorzy podają informacje dotyczące terminu rozpoczęcia emisji programu, dane występujących aktorów, czasami omawiają fabułę. W tym czasie równolegle emitowany dźwięk stanowiący integralną część audycji jest wyłączony (zatem jest tylko prezentacja wizualna) albo jest obniżona jego głośność, by nie kolidowała z treścią wypowiedzi lektora z wykorzystaniem techniki off (Lewicki 1997, s. 234-237). Komunikaty zawierają rekomendacje adresowane do widzów, np.: poleca, zaprasza, zaprasza o godzinie... ${ }^{19}$.

Niektóre stacje telewizyjne emitują fragment anonsowanej audycji, by po kilkusekundowej projekcji obrazu zamieścić, np. w centralnym punkcie ekranu, planszę zawierającą tytuł audycji, a następnie treść podkreślającą wartość propozycji. Mogą to być informacje dotyczące otrzymanych wyróżnień czy nagród bądź zagadkowo brzmiące pytania, twierdzenia, mobilizujące widza do refleksji. Wzmocnienie dokonuje się w chwili, gdy lektor odczytuje obecne na ekranie treści. Praktykę taką stosuje m.in. Paramount Channel. Rekomendując film pt. „Książę w Nowym Jorku”, na tle emitowanego fragmentu filmu wprowadzono planszę zawierającą anons Ksiażę z misja specjalna, tekst odczytał lektor, po czym opublikowano tytuł, a lektor wskazał termin emisji ${ }^{20}$.

W konsekwencji tak sformatowana treść komunikatu promującego program spełnia wszystkie wymogi kwalifikujące go jako samodzielną audycję podlegającą ochronie prawnej. Koszty jej produkcji ponosi nadawca.

4. Konkursy przeprowadzane na antenie danego nadawcy także są narzędziem prowadzanych działań autopromocyjnych. Z uwagi na wiele kontrowersji, Europejski Trybunał Sprawiedliwości 18 października 2007 roku wydał orzeczenie (sprawa C-195/06) dotyczące kwalifikacji przekazów, w których oferowany jest udział w konkursie z nagrodami poprzez wybieranie numeru o podwyższonej płatności, w świetle definicji ,telesprzedaży” oraz „reklamy telewizyjnej” sformułowanych w dyrektywie 89/552/EWG z 1989 roku (zmienionej dyrektywą 97/36/WE) - zwanej dyrektywą o telewizji bez granic. W uzasadnieniu stwierdzono, że „reklama jest formą autopromocji - gdy konkurs/gra zawiera treści bezpośrednio promujące zalety audycji danego nadawcy, szczególnie gdy zadawane pytania odwołują się do wiedzy o innych przekazach tego nadawcy i tym samym mają zachęcać do ich oglądania. Podobnie należy kwalifikować przypadki, gdy nagrody oferowane $\mathrm{w}$ danej grze są związane $\mathrm{z}$ audycją i służą jej promocji, np. nagrania video" (C-195/06).

W roku 2015 nadawca publiczny - TVP SA - zorganizował konkurs „Urodziny z TVP2”. Uczestnicy konkursu wysyłali „,[...] pod numer 7220 (2,46 zł z VAT) SMS-a zgłoszeniowego o treści podanej w wiadomości SMS lub na antenie TVP podczas programu «Pytanie na śniadanie» emitowanej na antenie TVP2 od 2 paź-

19 Obowiązek oddzielenia od pozostałych treści programu wynika z art. 25 Dyrektywy Parlamentu Europejskiego i Rady 2010/13/UE z dnia 10 marca 2010 r.

20 Materiał rozpowszechniany przez stację Paramount Channel w okresie od 26 lipca 2017 r. do dnia 8 sierpnia 2017 r., tj. do czasu emisji audycji. 
dziernika 2015 roku” (Konkurs „Urodziny z TVP2”...). Laureaci otrzymywali nagrody opisane w regulaminie konkursu.

5. Inną praktykowaną formą jest zamieszczanie, najczęściej w prawym górnym rogu ekranu, tzw. scrolli - to jest zapisanego w bryle najczęściej o kształcie prostokąta lub w formie paska u dołu ekranu graficznie zaprezentowanego anonsu o kolejnej audycji. Treść emitowana jest w trakcie trwania innej oferty programowej, dookreśla czas emisji i podaje tytuł przekazu. Widz ma wrażenie, że utwory nakładają się na siebie, wręcz ingerują w prezentowany materiał. „Ruch”, jaki powstaje w chwili emisji scrolla, ,przesuwa” wzrok odbiorcy na ten dodatkowy element obrazu, tym samym przenosi zainteresowanie widza.

Za niezgodne z przepisami prawa KRRiT uznała działania nadawcy TVP SA, który zamieszczając scrolla w trakcie emisji kolejnego odcinka serialu „Klan”, zapraszał widzów do obejrzenia nadawanego później programu „Świat się kręci” (100 tys. zł kary dla TVP za autopromocję...).

Nowe technologie pozwalają na jednoczesne emitowanie logo stacji - prawy górny róg ekranu, podawanie tytułu zapowiadanej audycji - po przeciwległej stronie ekranu poprzedzone określeniem typu już wkrótce, wkrótce oraz wprowadzeniem na tle emitowanego fragmentu audycji planszy podkreślającej wartość zapowiadanej projekcji. Lektor z kilkusekundowym opóźnieniem względem prezentowanych form graficznych powtarza treści zamieszczone na ekranie, doprecyzowując czas emisji.

\section{Cross-promotion}

Szczególne miejsce - zdaniem autorki publikacji - zajmuje cross-promotion. Termin ten oznacza: ,komplementarne i spójne działania prowadzone najczęściej przez dwie firmy/marki polegające na wzajemnym promowaniu produktów" (Cross-promocja...). Wyróżnić można cross-promotion wewnętrzną i zewnętrzną. W odniesieniu do analizowanego zagadnienia przyjąć należy, iż jest to działanie jednego nadawcy, który za pośrednictwem pozostających w jego dyspozycji anten (promocja wewnętrzna) i/lub współpracując trwale lub okolicznościowo z podmiotami medialnymi zewnętrznymi (promocja zewnętrzna), promuje własną ofertę.

Struktura organizacyjna medium ma istotne znaczenie w realizacji cross-promotion wewnętrznej. Biorąc pod uwagę, że współcześni nadawcy telewizyjni dysponują zazwyczaj więcej niż jedną anteną, wykorzystanie możliwości dotarcia do szerokiej grupy odbiorców uzasadnia celowość stosowanych rozwiązań.

W 2014 roku do Grupy TVN należały: TVN SA - 9 programów, NTL Radomsko Sp. z o.o. -1 program, Mango Media Sp. z o.o. - 1 program, Stawka Sp. z o.o. - 1 program oraz ITI Neovision SA - 17 programów telewizyjnych, 1 program radiowy oraz działalność operatorska na dwóch platformach. W 2014 roku do Grupy Polsat należały: Telewizja Polsat Sp. z o.o. -24 programy, Superstacja Sp. z o.o. 
- 1 program, Media Biznes Sp. z o.o. - 1 program oraz platforma Cyfrowy Polsat SA (wyłącznie operator). Spółka TVP SA w 2014 roku nadawała: 9 programów bezpłatnych, 3 programy płatne oraz 17 programów tworzonych przez oddziały terenowe. [...] tj. TVP 1, TVP 2, TVP Info, TVP Polonia, TVP Historia, TVP Kultura, TVP Rozrywka, TVP Regionalna, TVP Seriale, TVP Sport, TVP HD, TVP ABC (Informacja..., 2015, s. 32-34).

Zapraszanie do obejrzenia atrakcyjnej oferty przygotowanej za pośrednictwem innej anteny skierowane jest do innej grupy targetowej, a co za tym idzie, nie tylko ma wymiar informacyjny, ale również wpływa na decyzje widzów. Informacja może być przekazana tak w formie werbalnej, jak i graficznej - poprzez jej zamieszczenie u dołu ekranu na tzw. pasku ${ }^{21}$. Zakres treści obejmuje: czas emisji, wskazanie anteny oraz wydarzenia. Priorytetem jest budowanie relacji lojalnościowych z klientem. Za takie należy uznać działania prowadzone np. za pośrednictwem innych audycji: telewizji śniadaniowych, programów informacyjnych, publicystycznych, podczas trwania których prowadzący nie tylko często anonsują własne audycje, zapraszając na kolejne „wydanie”, „spotkanie" $\mathrm{z}$ widzami, informując o zaproszonych gościach, sygnalizując ciekawe tematy, które będą omawiane w przyszłości. Takie cechy posiadają także wypowiedzi zaproszonych gości, którzy zapowiadają relacje na antenie z organizowanych przez nich imprez. Zdarza się, że także dziennikarze zapraszają do obejrzenia wskazanych przez nich kolejnych audycji, np. prowadzący program informacyjny rekomendują wywiad dnia, program publicystyczny z udziałem zaproszonych polityków, ekspertów itp. (podają dane personalne zaproszonych gości, temat rozmowy, czas emisji). Wielość anten pozwala na proponowanie oferty tego samego nadawcy emitowanej w innym paśmie.

Niebagatelne znaczenie w podejmowanych działaniach promocyjnych przypisywane jest Internetowi. Prowadzenie bezpośredniego dialogu z klientem przez pocztę elektroniczną, fora, blogi, publikowanie zdjęć na Twitterze tworzy nową perspektywę w zakresie budowania relacji z widzem.

Realizacja cross-promotion zewnętrznej stanowić może konsekwencję umowy podpisanej z innym nadawcami lub wydawcami albo wynikać ze społecznego zainteresowania audycją, a zatem realizowana jest ad hoc. Słusznie zauważa A. Jupowicz-Ginalska, że

[...] mediami - z czysto informacyjnych lub rozrywkowych względów - interesują się inne media: głównie dlatego, że takie wiadomości są po prostu cenne dla odbiorców. Nasz rynek jest bardzo chłonny pod tym względem. W wielu tytułach prasowych wydzielono specjalne działy, które interesują się wyłącznie mediami (np. Gazeta Wyborcza, Dziennik, Rzeczpospolita, Wprost). Co więcej, na rynku funkcjonują już czasopisma oraz portale internetowe zajmujące się jedynie marketingiem, w tym branżą mediową (Jupowicz-Gignalska 2007, s. 35).

${ }^{21}$ Ticker (inaczej scroll lub $\mathrm{crawl}$ ) - pasek, na którym widoczne są najważniejsze informacje. Jest zwykle umieszczany w dolnej części ekranu telewizora i wyświetlany przez cały czas trwania programu telewizyjnego [https://pl.wikipedia.org/wiki/Ticker]. 
Prasa drukowana i radio stają się dodatkowym narzędziem komunikacji nadawcy telewizyjnego $\mathrm{z}$ otoczeniem. Wzajemna współpraca przynosi obustronne korzyści. Ma znaczenie nie tylko tradycyjna forma załączania do gazet programów telewizyjnych, tzw. insertów - wzrasta wówczas nakład wydania gazety, widz może się zapoznać zazwyczaj z tygodniową ofertą nadawcy, ale koherencję działań upatrywać należy i w innych praktykowanych rozwiązaniach.

Przywołać w tym miejscu można seriale telewizyjne. Z jednej strony, czytelnik/widz dzięki opisowi zostaje zaciekawiony wydarzeniami w kolejnym odcinku, z drugiej zaś publikacja zbiega się czasami z wolą artysty, którego angaż w serialu np. dobiega końca. Doświadczenie wskazuje, że z jednej strony autor scenariusza, dysponując wiedzą o zbliżającym się terminie zakończenia współpracy z aktorem, opracowuje w fabule filmu scenę ,finałową obecności danej postaci”, z drugiej zaś, informacja taka może być na tyle medialnym newsem, iż stanowi inspirację do jej upowszechniania przez innych dystrybutorów treści.

Scenariuszowe triki tuszujące prawdę, że aktor rezygnuje $\mathrm{z}$ dalszej współpracy $\mathrm{z}$ reżyserem i producentem, znajdowały zastosowanie $\mathrm{w}$ różnych filmach. Za spektakularne medialne przedsięwzięcie niepozostające bez wpływu na wielkość widowni uznać można w ostatnich latach śmierć Hanki Mostowiak z serialu „M jak miłość”. „Wypadek samochodowy, a potem pęknięcie tętniaka w mózgu - w ten sposób 7 listopada [dopisek własny 2011 r.] Hanka Mostowiak pożegnała się z życiem (a grająca ją Małgorzata Kożuchowska z serialem «M jak miłość»" (Jak odchodzi aktor (z serialu)...). Realistycznie wyreżyserowany scenariusz filmu prowokował do poszukiwania nekrologów i miejsca pochówku Hanki, okrzykniętej mianem bohaterki narodowej. „M jak miłość” wzbudził jeszcze większe zainteresowanie, kiedy Gazeta Wyborcza i inne media zachęcały widzów do oglądania premierowego wówczas odcinka serialu. W konsekwencji podjętych działań medialnych

862. odcinek „M jak miłość” obejrzało 7443 tys. widzów. Jak czytamy na stronie tvp.pl, serial przyciagnął „,zdecydowanie więcej” telewidzów niż nadawane o tej samej porze pozycje stacji komercyjnych: Mega Hit „Obcy kontra Predator II” w Polsacie i serial „W11. Wydział Śledczy” w TVN ${ }^{22}$.

Rocznica śmierci serialowej bohaterki była także powodem do rozważań o przyczynie i okolicznościach zgonu, a zarazem stała się podstawą dla kolejnych publikacji prasowych. Specjalnie przygotowane przez autorów scenariusze stanowiły rozwiązania interesujące pod względem PR-owskim, bowiem dzięki nim opinia publiczna zainteresowała się nie tylko losem serialowych bohaterów, ale również przyczynami rezygnacji aktora z dalszej współpracy z reżyserem serialu. Przywołać w tym miejscu można przykłady:

Teresy Żukowskiej (Ewa Skibińska), która zrezygnowała z gry w serialu „Pierwsza miłość", w serialowej rzeczywistości wyjechała do Azji, zaś faktycznie w ten

${ }_{22}$ Zob. http://www.polskieradio.pl/96/3/Artykul/476229,75-mln-widzow-obejrzalo-smierc-Hanki-Mostowiak. 
sposób zakończona została współpraca z reżyserem; Agnieszka Paliszewska, serialowa Jadzia Górka w „Barwach szczęścia”, także spektakularnie zakończyła swoją przygodę - bowiem upadła w kuchni, stając się bodaj pierwszą ofiarą epidemii tętniaków w polskich serialach, wskutek czego poniosła śmierć, [...] informacja o bezpłodności, jaką uzyskał Mareczek Zbiedź z „Na dobre i na złe” (Paweł Wilczak), skutkowała wybiegnięciem ze szpitala zdesperowanego pacjenta, który nie wrócił do swojej roli do dnia dzisiejszego (Jak odchodzi aktor (z serialu)...).

Zainteresowanie powodami rezygnacji z dalszej współpracy stworzyło przestrzeń dla dalszych publikacji prasowych.

\section{Promocja zewnętrzna}

W kontekście podejmowanych działań zewnętrznych wymienić należy:

- prezentacje oficjalne ramówek: wiosenne i jesienne zapowiedzi programowe,

- wydarzenia okazjonalne: uroczystości świąteczne, jubileusze.

Wyzwaniem dla zarządów nadawców telewizyjnych jest przygotowanie oferty programowej spełniającej oczekiwania widowni, ale także konkurencyjnej względem innych nadawców. Zadaniem działów marketingu/promocji jest opracowanie skutecznej strategii komunikacyjnej.

Każdego roku, zwłaszcza wiosną i jesienią, układ ramowy programów poddawany jest ocenie i co za tym idzie modyfikacji. Kryterium kontynuowania emisji audycji są wyniki oglądalności. Zainteresowanie daną audycją sprawia, że nadal emitowana jest $\mathrm{w}$ dotychczasowym czasie antenowym albo następuje jej przesunięcie do innego, wyższego pod względem liczby widzów pasma. Niskie współczynniki oglądalności mogą się przyczynić do zdjęcia audycji z anteny i wprowadzenia nowych, premierowych propozycji. Przygotowywane przez specjalnie do tego powołane zespoły programowe tzw. ramówki po raz pierwszy są publicznie prezentowane $\mathrm{w}$ trakcie specjalnie przygotowywanych konferencji prasowych i eventów. Poszczególni dostawcy usług audiowizualnych tak przygotowują harmonogram prezentowania oferty, że mimo silnej konkurencji nie odnotowano kolizji czasowej. Sprawia to wrażenie, że terminy są wcześniej konsultowane, co sprawia, że widz może obejrzeć każdą relację z oficjalnej prezentacji ramówki na określony sezon.

Organizowany event, którego integralną część stanowi konferencja prasowa, jest postrzegany jako wydarzenie kulturalne, w którym udział biorą reprezentanci różnych środowisk. W trakcie spotkania prezentowane są dotychczasowe osiągnięcia, ale szczególne miejsce zajmuje prezentacja dotycząca oferty programowej przygotowanej na nadchodzący sezon. Podczas konferencji prasowych obecni są także prowadzący program, komentatorzy, którzy swoją obecnością potwierdzają związek z daną stacją/antena, wypowiadają się na temat swojej audycji, anonsując nowe, atrakcyjne tematy i wzbudzając tym samym zainteresowanie widowni. 
Autorytet dziennikarza, np. Grażyny Torbickiej, która przez wiele lat prowadziła audycję „Kocham kino”, wpływa na popularność audycji.

Formuła ta wzbudza zainteresowanie widzów, internautów i czytelników prasy tradycyjnej. Relacje na żywo, reportaże, zamieszczane zdjęcia stanowią dodatkowe kanały informacyjne, a zarazem upowszechniają wiedzę na temat przyjętych rozwiązań. Wśród zapraszanych gości są politycy, celebryci, a zwłaszcza tzw. twarze stacji, czyli osoby, które z uwagi na emitowane najczęściej filmy, seriale, audycje kojarzone są z danym nadawcą. Do kategorii „twarze telewizji” zaliczyć można:

- osoby - aktor, prezenter, dziennikarz, komentator;

- rodziny serialowe.

Popularność audycji, niezależnie od gatunku, stanowi konsekwencję zaistnienia co najmniej jednego ze wskazanych kryteriów: interesująca i dobrze wyreżyserowana audycja, podejmowana problematyka, profesjonalizm prowadzącej/go audycję. Spełnienie chociażby jednego z nich spowodować może, że wcielający się w daną rolę aktor, a zwłaszcza gdy jest to bohater pozytywny - szybko zyskuje sympatię opinii publicznej. Instrumentalne traktowanie wykreowanych postaci staje się narzędziem, immamentnym składnikiem marketingowych działań, np. Ferdynand Kiepski, postać grana przez Andrzeja Grabowskiego w serialu emitowanym przez stację Polsat - „Świat według Kiepskich”23. Podobne praktyki stosowane są względem dziennikarzy. Komentatorzy, np. Włodzimierz Szaranowicz z TVP S.A. (redakcja sportowa), Mateusz Borek (redakcja sportowa Polsat), ale także prezenterzy prognozy pogody, np. Jarosław Kret (TVP S.A.), Marek Horczyczak (Polsat), jak i wielu innych, dzięki niemal codziennej obecności, przekazywaniu informacji i opisywaniu wydarzeń z danego dnia, czasami niekonwencjonalnej formie prowadzenia programu rozrywkowego czy relacjonowania imprezy sportowej, kształtują jakość usługi świadczonej przez nadawcę.

Wydarzenia kulturalne stają się przyczynkiem do spotkań z osobowościami telewizji. W trakcie ich trwania zaproszeni goście „pozostają do dyspozycji” operatorów kamer, fotografów, którzy utrwalają ich obecność na tzw. „ściankach” zawierających logo danej stacji, organizatora. Gwiazdy, udzielając wywiadów na tle logo stacji, anteny, często odwołują się do pracy zawodowej, opowiadają o losach serialowych bohaterów, podkreślają wkład i zaangażowanie nadawcy w proces budowania marki przez odpowiedni dobór treści.

Szczególne znaczenie zyskują konkursy i wyróżnienia. Przyznawane laury, np. „Złote Kaczki” lub „Orły”, są często „barometrem popularności”, wskazówką dla twórców i producentów audycji. Publikacje dotyczące laureatów konkursu popularyzowane są nie tylko na antenach rodzimej stacji, ale także komentowane w materiałach prasowych innych nadawców/wydawców. W roku 2017 najwięcej nagród przyznawanych w Plebiscycie „Telekamery Tele Tygodnia” zdobyła TVP S.A. Wśród nagrodzonych wymienić należy m.in. Michała Żebrowskiego z seria-

23 Sitcom emitowany od roku 1999. 
lu „Na dobre i na złe”, uznanego za najlepszego aktora; Barbarę Kurdej-Szatan - najlepsza aktorka; Marzenę Słupkowska, prezenterkę prognozy pogody. Doceniono także popularność emitowanych seriali.

Statuetka dla najlepszego serialu fabularno-dokumentalnego przypadła cyklowi „Na sygnale”. „Rolnik szuka żony” otrzymał wyróżnienie w kategorii program rozrywkowy. Złota Telekamera powędrowała natomiast do twórców serialu „Ranczo”. Wśród seriali bezkonkurencyjny okazał się „Ojciec Mateusz” (Telekamery 2017. Grad nagród dla gwiazd Telewizji Polskiej...) (Najchętniej oglądane seriale...).

Jak wskazano wyżej, popularność seriali telewizyjnych w Polsce uzasadnia liczba zasiadających przed odbiornikami telewizyjnymi widzów. „Klan”, „M jak miłość”, „Ranczo”, „Kiepscy” itd. - od lat mają stałą widownię.

W okresie od 22 sierpnia 2016 roku do 29 stycznia 2017 roku wśród cotygodniowych seriali największym zainteresowaniem cieszył się nadawany w niedziele o 20.25 w TVP1 serial „Ranczo”. Jego średnia oglądalność w jesiennej ramówce ub.r. wyniosła $5,30 \mathrm{mln}$ osób, co przełożyło się na 30,90 proc. udziału w rynku telewizyjnym wśród wszystkich widzów - wynika z danych Nielsen Audience Measurement, opracowanych przez portal Wirtualnemedia.pl. Drugie miejsce należy do emitowanego w środy o 20.45 w TVP2 „Na dobre i na złe”, którego średnia widownia w sezonie 2016/2017 wyniosła jak na razie 4,72 mln osób (29,71 proc. udziału) (Najchętniej oglądane seriale...).

Autorzy scenariuszy odpowiedzieli więc na zapotrzebowanie. Umiejscowili postacie w warunkach, w jakich funkcjonują widzowie, i zafundowali im takie same relacje międzyludzkie. W ten sposób rodzina stała się bohaterem zbiorowym polskich seriali, a jej problemy, zrozumiałe dla większości Polaków, są centrum akcji (Rodzina w polskich serialach...).

Słusznie zauważa autor publikacji pt. „Jakie są serialowe rodziny?”

Niemal każdy współczesny serial telewizyjny przemyca określone wzorce rodziny [...]. Rodzina jest najbardziej typowym wątkiem poruszanym we wszystkich polskich serialach telewizyjnych. Kreując obraz współczesnej rodziny, odwołują się do najbardziej podstawowych wartości, takich jak miłość, wierność, dobroć, oddanie, a także szacunek dla drugiego człowieka. Można zatem stwierdzić, iż treści, które oferują seriale telewizyjne, od dawna były obecne w kulturze, dlatego pełnią one rolę swoistej literatury. Seriale telewizyjne stały się nie tylko częścią kultury masowego przekazu, ale również częścią naszego rodzinnego życia (Jakie są serialowe rodziny...).

Utożsamianie rodzin filmowych $\mathrm{z}$ daną anteną pozostaje w subsumcji z prowadzonymi działaniami marketingowymi. „Członkowie” serialowej rodziny także pozują na tle „ścianek” stacji emitującej tę audycję.

Eventy to swoistego rodzaju cyklicznie organizowane wydarzenie kulturalne lub towarzyskie, stanowiące integralną część działań promocyjnych. Do pierwszej kategorii zakwalifikować można m.in. „Drzwi otwarte telewizji”, pikniki telewizyjne, imprezy rozrywkowe o charterze cyklicznym i okazjonalne, np., świąteczne, jubileuszowe, zaś do drugiej m.in. program rozrywkowy, np. „Imieniny 
u Krystyny”. Popularność serialu „Klan”, a zwłaszcza Krystyny Lubicz, stała się inspiracją do organizowania eventów w całym kraju. Imprezy masowe, np. „Zjazd Krystyn w Gdyni” (Pisera 2013), gale - m.in. „Imieniny u Krystyny” (Imieniny u Krystyny ...) - stanowią czynnik wzmacniający działania popularyzatorskie audycji. „W 2001 r. producenci serialu wpadli na pomysł, aby zrobić wielką imprezę z okazji imienin serialowej Krystyny oraz jubileuszowego 444. odcinka «Klanu»" (Imieniny u Krystyny ...). Zarówno podczas gali, jak również w materiałach PR-owskich podkreślano związek serialu z producentem - TVP S.A.

\section{Promocja mieszana}

Jedną z form promocji praktykowaną przez wielu przedsiębiorców jest sponsoring. Sponsorowanie audycji, polegające na eksponowaniu billboardu sponsorskiego, wskazuje podmiot wstępujący w prawa sponsora. Werbalnie i wizualnie zaprezentowany komunikat wzbudza u odbiorców pozytywne skojarzenia. Prezentując informacje o sponsorze, wskazuje także na audycję objętą tego typu działaniami. Podmioty medialne dla oznaczenia praktyk sponsorskich stosują pojęcie patronat medialny. Sprawując pieczę nad danym wydarzeniem, promują je na swoich antenach, każdorazowo podkreślając fakt objęcia patronatem. W relacjach bezpośrednich, powtórkach, dostrzec można logo stacji oraz powielany jest anons egzemplifikujący treść o patronacie medialnym.

\section{Podsumowanie}

Zarządzanie mediami wymaga nie tylko odpowiedniego doboru kadry, umiejętnego gospodarowania zasobami finansowymi, ale przede wszystkim zaproponowania audycji oczekiwanych przez widzów. W dobie olbrzymiej konkurencji kluczowe znaczenie ma program telewizyjny, jego układ wynikający ze znajomości upodobań współczesnego widza. Z punktu widzenia ekonomicznego jest to towar, produkt, który należy opakować tak, by przynosił wymierne korzyści. $\mathrm{Z}$ tego względu zarządy stacji poszukują nowych rozwiązań pozwalających na jego popularyzowanie. Zmiana paradygmatu komunikowania, w którym odbiorca zyskał nową, aktywną rolę w tym procesie, nie pozostaje bez wpływu na ostateczny kształt oferty programowej nadawcy. Rozwój technologii i zmiany, jakie obserwujemy w ostatnich latach, potwierdziły, że odpowiedzialne za politykę programową działy charakteryzuje wysoki poziom kreatywności - konieczny dla budowania skutecznego systemu komunikacji z widzem, celem przekonania o atrakcyjności przygotowanej oferty. Przedsięwzięcia autopromocyjne charakteryzuje różnorodność działań i szeroki wachlarz stosowanych rozwiązań. Wykorzystanie własnych, „rodzimych” anten, stron internetowych, współpraca $\mathrm{z}$ innymi nadawcami i wydawcami mediów, angażowanie aktorów, celebrytów, 
organizowanie eventów - wszystko to ma wzmocnić zakres posiadanej wiedzy o antenie, stacji i jej programie. W ocenie autorki w przyszłości konwersja przekazu będzie stanowiła fundament efektywnego działania. Jak podkreślono w artykule, czynnikiem determinującym zachowania społeczne jest szybkość przepływu informacji. Zatem za priorytetowe uznać należy wykorzystanie możliwości technologicznych do rozszerzenia zasięgu świadczonych usług audiowizualnych, tak by odbiorca mógł uzyskać wiedzę za pośrednictwem dostępnych urządzeń mobilnych niezależnie od miejsca pobytu i czasu.

Kluczem do sukcesu marketingowego jest zbudowanie relacji wzajemności z odbiorcą (mechanizmu komunikacyjnego sprzężenia zwrotnego) i przywiązania do kreowanej marki. Powyższym celom ma służyć łatwość dostępu do aplikacji internetowych, a co za tym idzie - mniej skomplikowany sposób budowania treści na stronie internetowej.

Za istotne uznać także należy wzmocnienie działań cross-promotion, np. poprzez zacieśnienie współpracy z nadawcami radiowymi. Podobnie jak w przypadku innych podmiotów gospodarczych, odpowiednio opracowane działania marketingowe nadawców, a zwłaszcza autopromocja, w coraz większym stopniu decydują o wyborach dokonywanych przez widownię. Postulować także należy zmianę aktualnie obowiązujących rozwiązań prawnych i potrzebę ich weryfikacji, wynikającą m.in. z wdrażanych rozwiązań technologicznych.

W aktualnym stanie prawnym - mimo deklaracji o potrzebie zmian - nie rozstrzygnięto w sposób klarowny, jak rozumieć należy działania autopromocyjne oraz co powinna zawierać treść takiego przekazu i jakie są warunki techniczne jego emisji. Zdaniem autorki, doprecyzowanie zasad emisji autopromocji ułatwiłoby nadawcom korzystanie $\mathrm{z}$ tej formy promocji usługi medialnej.

\section{Bibliografia}

Akty prawne

Wyrok Trybunału (czwarta izba) z dnia 18 października 2007 r. Kommunikationsbehörde Austria (KommAustria) przeciwko Österreichischer Rundfunk (ORF). Wniosek o wydanie orzeczenia w trybie prejudycjalnym: Bundeskommunikationssenat - Austria, sprawa C-195/06.

Dyrektywa Parlamentu Europejskiego i Rady 2000/31/WE z dnia 8 czerwca 2000 r. w sprawie niektórych aspektów prawnych usług społeczeństwa informacyjnego, w szczególności handlu elektronicznego w ramach rynku wewnętrznego (dyrektywa o handlu elektronicznym). Dz.Urz. L 178, 17.07.2000 P. 0001-0016.

Dyrektywa Parlamentu Europejskiego i Rady 2010/13/UE z dnia 10 marca 2010 r. w sprawie koordynacji niektórych przepisów ustawowych, wykonawczych i administracyjnych państw członkowskich dotyczących świadczenia audiowizualnych usług medialnych (dyrektywa o audiowizualnych usługach medialnych) (wersja ujednolicona). (Tekst mający znaczenie dla EOG). Dz.Urz. UE 15.04.2010.L 95/1. 
Rozporządzenie Krajowej Rady Radiofonii i Telewizji z dnia 30 czerwca 2011 r. w sprawie sposobu prowadzenia w programach radiowych i telewizyjnych działalności reklamowej i telesprzedaży. Dz.U. 2011, nr 150, poz. 895.

Rozporządzenie z dnia 30 czerwca 2011 r. w sprawie sposobu prowadzenia w programach radiowych i telewizyjnych działalności reklamowej i telesprzedaży. Dz.U. 2011, nr 150, poz. $895 \mathrm{z}$ późn. zm.

Ustawa z dnia 26 stycznia 1984 r. Prawo prasowe. Dz.U. 1984, nr 5, poz. 24 z późn. zm.

Ustawa z dnia 29 grudnia 1992 r. o radiofonii i telewizji. Dz.U. 2016, poz. 639.

\section{Opracowania}

Bernays E. (2011). Crystallizing Public Opinion. London.

Brady R., Forrest E., Mizerski R. (2002). Marketing w Internecie. Warszawa.

Budzyński W. (1998). Public relations. Zarządzanie reputacją firmy. Warszawa.

Cutlip S., Center A. (1978). Effective Public Relations. Upper Saddle River, NJ.

Drucker P. (2000). Zarządzanie w XXI wieku. Warszawa.

Earl M. J. (2000). Every Business is an Information Business. W: D.A. Marchand, T.H. Davenport, T. Dickson (red.). Mastering Information Management (s. 92-102). London.

Garcarek-Sikorska A. (2013). Cechy gatunkowe morning show na przykładzie audycji „Wstawaj, szkoda dnia" w radiu RMF FM. Acta Universitas Lodziensis Folia Litteraturaria Polonica, vol. 2, s. 201-210.

Gawroński J. (2014). Zarządzanie mediami w sformalizowanej strukturze przestrzeni medialnej. Zarzadzanie w Kulturze, z. 4, s. 411-422.

Harlow R. (1976). Building a Public Relation Definition. Public Relation Review, vol. 2, s. $34-42$.

Informacja o podstawowych problemach radiofonii i telewizji w 2015 roku (2015). KRRiT. Warszawa.

Jabłoński A., Sobkowiak L. (red.) (2002). Marketing polityczny w teorii i praktyce. Wrocław.

Jupowicz-Gignalska A. (2007). Promowanie mediów w mediach. Ze studiów nad marketingiem medialnym. W: J. Olędzki (red.). Public relations. Społeczne wyzwania (s. 33-55). Warszawa.

Jupowicz-Ginalska A. (2010). Marketing medialny. Warszawa.

Jupowicz-Ginalska A. (2013). Efektywna promocja własna jako źródło wizerunkowego sukcesu organizacji medialnej - na przykładzie TVN S.A. Zeszyty Naukowe Uniwersytetu Przyrodniczego-Humanistycznego w Siedlcach, seria: Administracja i Zarządzanie, nr 98, s. 383-401.

Kisielnicki J., Sroka H. (2005). Systemy informacyjne biznesu. Warszawa.

Lewicki B.W. (1997). Kino i telewizja. Warszawa.

Namysłowska M. (red.) (2012). Reklama. Aspekty prawne. Warszawa.

Nierenberg B. (2011). Zarządzanie mediami. Ujęcie systemowe. Kraków.

Rosenfeld L., Morville P. (2003). Architektura informacji w serwisach internetowych. Gliwice.

Szmelter A. (2015). Wpływ konwergencji mediów na komunikację w korporacjach globalnych.

W: K. Kopecka-Piech (red.). Zmiany medialne i komunikacyjne. Media, wizerunek, biznes (s. 205-218). Gdańsk.

Sztucki T. (1997). Promocja sztuka pozyskiwania nabywców. Warszawa

Traple E., Adamczyk J., Barta B., Konarski X., Kulis W., Litwiński P., Okoń Z., Podrecki P., Sibiga G., Świerczyński M., Targosz T. (2007). Prawo reklamy i promocji. Warszawa.

Wójcik K. (1997). Public relations od A do Z. Warszawa. 


\section{Źródła internetowe}

100 tys. zł kary dla TVP za autopromocję i włączenie produktu w akcję serialu [http://www. press.pl/tresc/37063,100-tys_-zl-kary-dla-tvp-za-autopromocje-i-wlaczenie-produktu-w-akcje-serialu; 29.09.2014].

Bez kary dla Polsatu za autopromocję w czasie filmu „Życie Pi”. „Kłopoty techniczne” [http:// www.wirtualnemedia.pl/artykul/bez-kary-dla-polsatu-za-autopromocje-w-czasie-filmu-zycie-pi-klopoty-techniczne; 6.12.2016].

Cross-promocja [http://mojafirma.infor.pl/biznes-finanse/211296,2,Crosspromocja.html; 18.12. 2016].

Definicje NET [http://definicja.net/co-to-jest-Autopromocja; 6.12.2016].

Multiscreening powszechny wśród internautów, w górę shifting (infografika) [http://www.wirtualnemedia.pl/artykul/multiscreening-powszechny-wsrod-internautow-w-gore-shifting-infografika; 25.01.2015].

Imieniny u Krystyny, czyli wielka gala gwiazd „Klanu” [http://www.fakt.pl/kobieta/plotki/tak-sie-bawily-gwiazdy-klanu-w-2001-r/mykr9c4; 30.04.2017].

Jak odchodzi aktor (z serialu) [http://www.newsweek.pl/kultura/wiadomosci-kulturalne/jak-odchodzi-aktor--z-serialu-,84216,1,1.html; 22.04.2017].

Jakie są serialowe rodziny? [http://swiatseriali.interia.pl/news/news-jakie-sa-serialowe-rodziny,nId,280532; 30.05.2010].

Konkurs „Urodziny z TVP2” [https://www.e-konkursy.info/konkurs/konkurs-urodziny-z-tvp2. html\#.WYD31tKLQ_4; 25.04.2017].

KRRiT dostała skargę, więc zajmie się autopromocją Polsatu w „Życiu Pi” [http://www.wirtualnemedia.pl/artykul/krrit-dostala-skarge-wiec-zajmie-sie-autopromocja-polsatu-w-zyciu-pi; 4.11.2015].

Najchętniej oglądane seriale cotygodniowe pokazuje TVP. „Ranczo” na czele [http://www. wirtualnemedia.pl/artykul/najchetniej-ogladane-seriale-w-polskiej-telewizji; 11.02.2017].

Pisera K. (2013). Zjazd Krystyn w Gdyni [http://gdansk.naszemiasto.pl/artykul/zjazd-krystyn-w-gdyni-przez-jeden-dzien-w-miescie-beda,1751873,art,t,id,tm.html; 13.04.2017].

Rączka M. (2015). Ile czasu spędzają przed telewizorem mieszkańcy całego świata?, 11.12.2015 [https://naekranie.pl/aktualnosci/ile-czasu-spedzaja-przed-telewizorem-mieszkancy-calego-swiata-764466; 15.04.2017].

Rodzina w polskich serialach [http://wiadomosci.onet.pl/kiosk/rodzina-w-polskich-serialach/ xcsct; 1.04.2017].

Słownik Diki [https://www.diki.pl/slownik-angielskiego?q=trailer; 2.04.2017].

Słownik języka polskiego [http://sjp.pwn.pl/sjp/autopromocja;2442106; 2.04.2017].

Sobczyński J. (2012). Panteon najsłynniejszych polskich spikerów. Głos Wielkopolski, 1.05.2012 [http://www.gloswielkopolski.pl/artykul/565165,panteon-najslynniejszych-polskich-spikerow-filmy,id,t.html; 20.01.2017].

Telekamery 2017. Grad nagród dla gwiazd Telewizji Polskiej [http://www.tvp.info/28857047/ telekamery-2017-grad-nagrod-dla-gwiazd-telewizji-polskiej; 30.01.2017].

\section{STRESZCZENIE}

W drugiej dekadzie XXI wieku działalność podmiotów gospodarczych związana jest nie tylko z produkcją czy świadczeniem usług, ale coraz większe znaczenie zyskują podejmowane działania marketingowe. Dotarcie do potencjalnych klientów z informacją dotyczącą oferty ma istotne znaczenie w procesie dążenia do sukcesu ekonomicznego. Służą temu wyznaczone 
w strategiach rozwoju działania, odpowiednio dobrane metody i narzędzia ich realizacji. Kompleksowe ich opracowanie ułatwia realizację zadań, tak pod względem podmiotowym, jak i przedmiotowym, a co za tym idzie stanowi o konkurencyjności względem innych podmiotów wymiany towarowo-usługowej.

Zarządzanie przedsiębiorstwem medialnym wymaga stosowania mechanizmów właściwych innym podmiotom gospodarczym w celu wypracowania marży netto. Specyfika przedmiotu działalności, tj. świadczenie usługi audiowizualnej, zobowiązuje m.in. do kształtowania oferty programowej, informowania o planowanych emisjach audycji w celu wpływania na dokonywane przez widownię wybory.

Słowa kluczowe: autopromocja, zarządzanie mediami, architektura informacji, program 